Check for updates

The BMJ

fgodlee@bmi.com Follow Fiona on Twitter @fgodlee

Cite this as: $B M / 2021 ; 373: n 968$ http://dx.doi.org/10.1136/bmj.n968 Published: 15 April 2021

\title{
Covid-19: Vaccine woes highlight vital role of traditional public health
}

\section{Fiona Godlee editor in chief}

Covid-19 still dominates the global consciousness and therefore The BMJ's coverage. This is unlikely soon to change, with the pandemic still growing exponentially. ${ }^{1}$ This year has already seen over $50 \%$ more deaths worldwide than the whole of $2020,{ }^{2}$ and, while lockdown and vaccines have cut deaths and illness in the UK, the government's advisers warn that plans for easing restrictions risk a serious summer resurgence. ${ }^{3}$

Vaccination remains a source of great hope, and in the UK the programme has showcased what the NHS can do when given the remit and resources. ${ }^{4}$ But, despite its early promise, the Oxford University-AstraZeneca vaccine is now mired in confusion, conflict, and doubt. Explanations range from the company's inexperience as a vaccine producer and its poor communication to toxic geopolitics and even a profit motivated attack on this not-for-profit venture. ${ }^{5}$ Whatever the cause, the real concern is the effect of increased vaccine hesitancy on the wider vaccination programme.

Links with rare serious thrombotic events, ${ }^{6}$ though not yet proved to be causally related, have only added to the AstraZeneca vaccine's woes, ${ }^{7}$ now also shared by the Johnson \& Johnson vaccine. ${ }^{8}$ Speculation on the mechanism has led some royal colleges to issue guidance on how to manage patients who are concerned about symptoms after receiving the vaccine. ${ }^{7910}$

Vaccines are a key to preventing further lockdowns, and vaccine passports may eventually play a role, if properly designed. ${ }^{11}$ But just as important are traditional public health measures to control transmission, especially preventing airborne spread. ${ }^{12}$

Clarity on the importance of aerosols comes too late for the key workers who have died or developed post-covid illness as a result of inadequate ventilation and personal protective equipment. But it should bring new urgency to calls for an independent inquiry into the UK's handling of the pandemic. ${ }^{1314}$ There is much that can and must be done now to provide safe workspaces, schools, and healthcare facilities, to establish proper systems of test, trace, isolate, and support, and to prevent covid-19 becoming entrenched as a disease of poverty. ${ }^{15}$ Worldwide, preventing the next pandemic will require a properly governed and financed virus surveillance system. ${ }^{16}$

So, yes, it's still covid, covid, covid in The BMJ. But other articles continue to remind us all that medicine must manage other conditions too: urinary tract infection, ${ }^{17}$ otitis externa, ${ }^{18}$ polycystic ovary syndrome, ${ }^{19}$ and chronic pain. ${ }^{20}$ More than 4.5 million people missed out on hospital treatment in England last year, ${ }^{21}$ a sobering reminder of the need to restore routine care.
1 Beaumont P Covid pandemic still growing exponentially, WHO says. Guardian. 12 Apr 2021. https://www.theguardian.com/world/2021/apr/12/covid-pandemic-still-growing-exponentially-who-says.

2 Appleby J. UK deaths in 2020: how do they compare with previous years?BM/2021;373:n896doi: 10.1136/bmi.n896.

3 Torjesen I. Covid-19: Hospital admissions and deaths could rise this summer, modellers warn. BMJ2021;373:n923doi: 10.1136/bmi.n923.

4 Ham C. Can the success of the NHS vaccination rollout be applied in other areas of healthcare? BMJ Opinion. 7 Apr 2021. https://blogs.bmi.com/bmi/2021/04/07/chris-ham-can-the-success-of-thenhs-vaccination-rollout-be-applied-in-other-areas-of-healthcare.

$5 \quad$ Wise J. Covid-19: How AstraZeneca lost the vaccine PR war. BMJ 2021;373:n921doi: 10.1136/bmj.n921.

6 Hunter PR. Thrombosis after covid-19 vaccination. BMJ 2021;373:n958doi: 10.1136/bmj.n958.

7 Wise J. Covid-19: Rare immune response may cause clots after AstraZeneca vaccine, say researchers. BMJ2021;373:n954doi: 10.1136/bmj.n954.

8 Mahase E. Covid-19: US suspends Johnson and Johnson vaccine rollout over blood clots. BMJ2021;373:n970doi: 10.1136/bmj.n970.

9 Greinacher A, Thiele T, Warkentin TE, Weisser K, Kyrle PA, Eichinger S. Thrombotic thrombocytopenia after ChAdOX1 nCov-19 vaccination. N Engl J Med 2021. doi: 10.1056/NEJMoa2104840.

10 Rimmer A. Covid-19: Colleges publish guidance after patients attend emergency departments with vaccine concerns. BMJ 2021;373:n960doi: 10.1136/bmj.n960.

11 Osama T, Razai MS, Majeed A. Covid-19 vaccine passports: access, equity, and ethics. BM/2021;373:n861doi: 10.1136/bmj.n861.

12 Tang JW, Marr LC, Li Y, Dancer SJ. Covid-19 has redefined airborne transmission. BMJ2021;373:n913doi: 10.1136/bmj.n913.

13 Hurley R. Sixty seconds on ... a covid-19 inquiry. BM 2021;373:n952doi: 10.1136/bmj.n952.

14 Adebowale V, Alderson D, Burn W, etal. Covid-19: Call for a rapid forward looking review of the UK's preparedness for a second wave-an open letter to the leaders of all UK political parties. BM 2020;369:m2514doi: 10.1136/bmj.m2514.

15 Pagel C. A very real danger that covid-19 will become entrenched as a disease of poverty. BMJ Opinion. 9 Apr 2021 https://blogs.bmj.com/bmi/2021/04/09/christina-pagel-a-very-real-dangerthat-covid-19-will-become-entrenched-as-a-disease-of-poverty.

16 Carroll D, Morzaria S, Briand S, etal. Preventing the next pandemic: the power of a global viral surveillance network. BMj 2021;372:n485doi: 10.1136/bmj.n485.

17 Hoffmann TC, Bakhit M, Del Mar C. Uncomplicated urinary tract infection in women. BM/2021;372:n725doi: 10.1136/bmj.n725.

18 Barry V, Bhamra N, Balai E, Maung S. Otitis externa. BMJ 2021;372:n714doi: 10.1136/bmj.n714.

19 Copp T, et al. Driven by good intentions: why widening the diagnostic criteria for polycystic ovary syndrome may be harming women. BMJ Opinion. 30 Mar 2021. https://blogs.bmi.com/bmi/2021/03/30/driven-by-good-intentions-why-widening-the-diagnostic-criteria-for-polycystic-ovary-syndromemay-be-harming-women.

20 Kmietowicz Z. Doctors raise concerns about NICE guidelines on chronic primary pain. BMJ 2021;373:n942doi: 10.1136/bmj.n942.

21 Gardner T, Fraser C. Longer waits, missing patients and catching up. Health Foundation. 13 Apr 2021. https://www.health.org.uk/news-and-comment/charts-and-infographics/how-is-elective-care-coping-with-the-continuing-impact-of-covid-19.

This article is made freely available for use in accordance with BMJ's website terms and conditions for the duration of the covid-19 pandemic or until otherwise determined by BMJ. You may use, download and print the article for any lawful, non-commercial purpose (including text and data mining) provided that all copyright notices and trade marks are retained. 